\title{
Injury biomechanics of the cervical spine in car collisions - Some needs for further research
}

\author{
Prof. Mats Y. Svensson*
}

\section{Background}

The incidence of soft tissue neck injuries in car collisions has been on the increase during the last two decades and these injuries cause enormous costs to society and the insurance business today. This is the reason behind the intensified research efforts and the great number of important publications in this field in recent years. YOGANANDAN AND PINTAR (2000a) present a condensed overview of the latest development in the field.

A ccident data have been collected in a number of studies and we are beginning to get a clearer view of the injury incidence as a function of various parameters. The injury risk appears to be the greatest in rear-end collisions but frontal collisions as well as side collisions stand for a significant portion of these injuries (Krafft, 2000; Temming and Zobel, 1998; JAKOBSSON ET AL., 2000B). The neck injury symptoms appear to be very similar for all impact directions (MINTON ET AL., 2000). The injury risk differs between seating positions. In rear-end collisions the rear seat generally is safer (LöVSUND ET AL., 1988; JAKOBSSON ET AL., 2000A ). The risk of initial neck symptoms increases with velocity change $(\Delta v)$, but among those initially injured the acceleration pulse appears to be more important than the $\Delta \mathrm{V}$ as a predictor of risk of long term consequences (KRAFFT, 2000; KULLGREN ET AL., 2000). The neck injury risk differs significantly between different car models of similar size in rear impacts (KRAFFT, 2000). Taller drivers have an increased injury risk in rear impacts (JAKOBSSON, 2000) and the injury risk increases if the vehicle occupant is unaware of the impending accident (RYAN ET A L., 1994).

A number of experimental studies on volunteers and post mortem human subjects have been reported. There is a relatively good view of the overall body kinematics in different crash directions. The typical neck loading in a car accident is caused by the acceleration of the torso resulting in a neck bending motion illustrated in Figure 1. The thoracic spine normally undergoes some type of bending motion in this type of event. In rear-end collisions the thoracic kyphosis is straightened resulting in an elevation and a rearward tilt of the $T 1$ vertebra (DAVIDSSON ET AL., 1998; VAN DEN KROONENBERG, 1998; OnO ET AL., 2000). Several studies have focused also on the detailed motion of the cervical spinal segments during rear-end impact loading (ONO ET AL., 1997; PANJABI ET AL., 1999; W In Kelstein ET AL., 1999; YOganANdAN ANd PINTAR, 2000B; DENG ET AL., 2000). The intervertebral motion appears to deviate from normal physiologic human neck bending motion.
Two new crash dummy prototypes for rear-end collision testing have been presented, BioRID (DAVIDSSON, 1999; DAVIDSSON, 2000; DAVIDSSON ET AL., 1999) (Fig. 2) and RID2 (CAPPON ET AL., 2000). The two dummies enable a more detailed assessment of the human body kinematics in rear end impacts. This will, for instance, improve the prediction of the contact conditions between the head and the head-restraint. In the future, with this type of dummy and with appropriate dummy instrumentation, it will probably be possible to measure injury criteria that correlate to neck injury risk.

Soft tissue injuries have been found in several different structures and locations in the neck region in experimental studies and autopsy studies. In a recent study YoGA NA NDA N ET A L. (2000) reported injuries to several ligaments, the intervertebral discs and the facet joint structures. SIEGMUND AND BRAult (2000) and Brault et AL. (2000) presented indications of muscle injury due to eccentric muscle loading in the early phase of the neck motion in rear impacts. TAYLOR ET AL. (1998) reported interstitial haemorrhage in cervical dorsal root ganglia in an autopsy study of victims who had sustained severe inertial neck loading during impacts to the torso or to the head. The structures around the ganglia were mostly uninjured. These findings correlate to experimental findings in pigs of nerve cell membrane dysfunction in cervical spinal root ganglia reported by SVENSSON ET A L. (2000).

Several neck injury mechanisms and neck injury criteria have been proposed during recent years. Two criteria, $\mathrm{Nij}$ (KLeIN Berger et AL., 1998) and N km (M uSER ET A L., 2000), use combinations of neck loads to predict the risk of injury to the skeletal spine. The IV-NIC (PANJABI ET AL., 1999) uses the angular displacement between adjacent vertebrae to estimate the risk of injury to various structures of the intervertebral joints. The correlation between these three injury criteria and the risk of long term soft tissue neck injury has not (to the author's knowledge) yet been established. The $\mathrm{N}$ eck Injury Criterion (NIC) (BOSTRÖM ET AL., 2000) uses differential horizontal acceleration between the head and the $T 1$ vertebra to assess the neck injury risk. The NIC was initially based on experimental findings summarised by SVENSSON ET A L. (2000). It correlates to transient pressure gradients in the central nervous system during experimental whiplash and these were hypothesised to correlate to cervical spinal ganglion injury. NIC would also function as a predictor of other types of injury mechanisms and indications of correlation between NIC and long term neck injury risk have been presented (BOSTRÖM ET AL., 2000).

C rash Safety D ivision, C halmers U niversity of Technology, G öteborg, Sweden

C orrespondence: Dr M ats Svensson, Crash Safety Division, C halmers U niversity of Technology, SE-412 96 G öteborg, Sweden.

Telephone +46 31772 3644, fax +46 31772 3690, e-mail mats. svensson@me. chalmers. se 


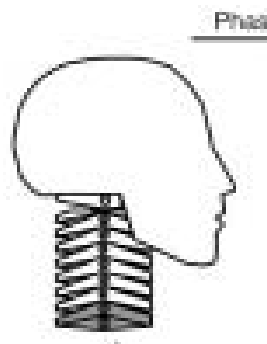

a)

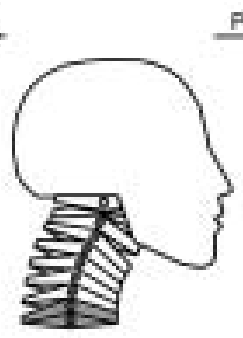

b)
Phase 2

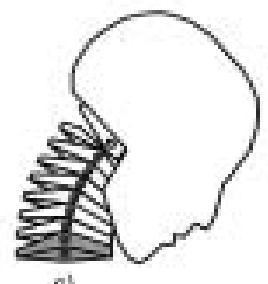

c)
Figure la Schematic drawing of the head-neck motion during a frontal collision. Phase 1: Protraction motion. Phase 2: Flexion motion.

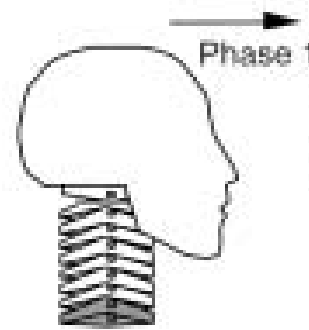

a)

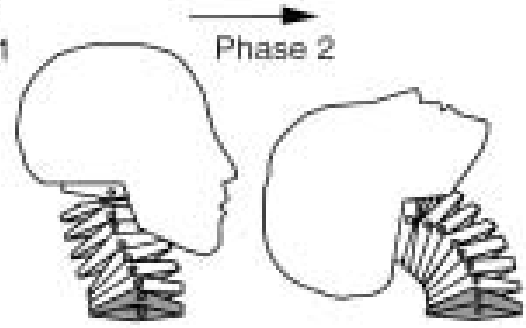

b)

c)
Figure 1b Schematic drawing of the head-neck motion during a rearend collision. Phase 1: Retraction motion. Phase 2: Extension motion.

The injury symptoms have been described in a large number of papers (e.g. StuRzen Eg Ger ET A L., 1995; SPITZER ET A L., 1995). It is important to distinguish between initial symptoms and long term symptoms (KRA FFT, 2000). Long term (chronic) whiplash symptoms appear to be associated with central pain sensitisation (SHEATHER-REID A N D C OHEN, 1998; JOHANSEN ET A L., 1999). The exact origin of this pain sensitisation has not been established. Successful treatment methods could possibly provide a clue. BYRN ET AL. (1993) reported significantly reduced symptoms during a time period after subcutaneous sterile water injections on the back of the neck. BoGDUk (2000) reported pain relief in about 50 percent of the patients after coagulation of the small nerves that innervate the facet joint that is associated with the painful dermatome.

\section{Synthesis}

It appears likely that several types of neck injury may appear as a result of a whiplash trauma (muscles, ligaments, facet joint, discs, nerve tissue etc.). Several injury types may be present in the same patient at the same time. The relation between these possible injuries and the large set of known whiplash symptoms (neck pain, head ache, shoulder pain, neurological symptoms etc.) is unclear. It would be of particular interest to know which one (ones) of these injuries that would result in long term symptoms and central pain sensitisation. It would then also be of interest to know which injury mechanism is responsible for this particular injury.

A the initial symptom stage, arm pain and high symptom intensity seem to correlate to an increased risk of long term consequences (STURZENEGGER, 1995; KARLSSON ET A L., 2000). The apparent influence of the crash pulse on the risk of long term consequences in patients with initial symptoms (KRAFFT,

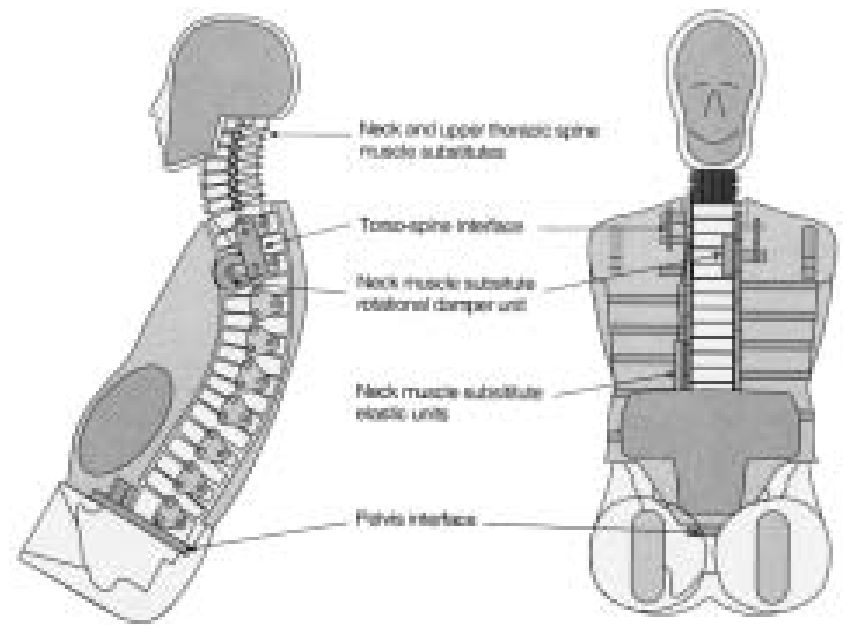

Figure 2: Schematic of the new BioRID II torso, arm attachments, spine, modified H ybrid III pelvis and head (DAVIDSSON ET AL., 1999).

2000) indicate that there could be a separate injury and a separate injury mechanism behind the long term symptoms. This particular injury could, in the acute stage, often co-exist with other injuries that normal ly heal without causing residual pain. STURZENEGGER ET AL. (1995) found a higher risk of Iong term symptoms in those patients that were injured in a rear-end collision as compared to other impact types. This may indicate that one particular injury (which may cause long term symptoms) is more likely to occur in a rear impact.

In more peripheral parts of the body most of these injury types (tissue types) normally recover without long term pain and central pain sensitisation. Is there something special about the neck region that makes one or several of these injuries result in long term pain? CAVANAUGH (2000), for instance, explained that the facet joint capsules are particularly rich in nerve endings and this is why an injury at this point would be a likely reason for long lasting pain. This pain may cause referred pain, e.g. in the shoulder region. Facet joint capsule strain and pinching has been shown in post mortem human subjects in rear impact testing (YOGANANDAN AND PINTAR, 2000B; DENG ET A L., 2000). It is, however, not known whether the same type of mechanisms may occur also in side impacts and frontal impacts. Is there some type of structure that is unique for the neck? T he spinal nerve root ganglia would be an example of such a structure. CAVANAUGH (2000) explained that injury to the dorsal root ganglia is likely to cause radiating pain to dermatomes of, for instance, the shoulders and the arms. These symptoms are, as mentioned earlier, known to correlate to increased risk of long term consequences. Cervical dorsal root ganglion injuries have been observed in various impact directions (SVENSSON ET AL., 2000, TAYLOR ET AL., 1998) and would explain the similarity in symptoms between different impact directions.

It can be concluded that we have a lot of exciting research work ahead of us before we get a complete understanding of the whiplash problem. But once we have this understanding, we will have a much better chance of developing accurate diagnosis methods, effective treatment and good preventive measures in vehicles. 


\section{REFERENCES}

1. BOGDUK, N. (2000): A n overview of W hiplash. In: Eds. YoganA NA N , N ; PINTAR, F.A .: Frontiers in W hiplash Trauma. IOS Press, The N etherlands, ISBN 158603012 4, pp. 3-9.

2. Boström, O.; HÅLAND, Y.; LÖVSUND L.; SVENSSOM, M.Y. (2000): $\mathrm{N}$ eck Injury C riterion ( $\mathrm{NIC}$ ) and its Relevance to Various Possible N eck Injury M echanisms. In: Eds. Yogan Anda n, N ; PINTAR, F.A.: Frontiers in W hiplash Trauma. IOS Press, The N etherlands, ISBN 1586030124

3. BRAult, J.R.; Siegmund, G.P.; W heeler, J.B. (2000): C ervical muscle response during whiplash: evidence of a lengthening muscle contraction. Clinical Biomechanics 15 (2000) 426-435.

4. Byrn C, OLSSON I, FAlkheden L, LINDH M, Hosterey U, Fogelberg M , LINDER LE, BUNKETORP (1993): Subcutaneous sterile water injections for chronic neck and shoulder pain following whiplash injuries. Lancet. 1993 Feb 20; 341(8843):449-52.

5. Cappon, H.J.; PhilipPens, M.M.G.R.; VAn Ratingen, M.R W ISM A N S, J.S.H.M. (2000): Evaluation of Dummy Behaviour During Low Severeity Rear Impact. Proc. IR C O BI C onf. M ontpellier, France, September 20-22, pp. 53-66.

6. CAVANAUGH, I.M. (2000): N europhysiology and N euroanatomy of N eck Pain. In: Eds. Yogan A N DA N, N; PINTAR, F.A .: Frontiers in W hiplash Trauma. IOS Press, The N etherlands, ISBN 158603012 4, pp. 79-96.

7. DAVIDSSON, J. (1999): BioRID II final report. Crash Safety Division, Chalmers Ú niversity of Technology, G öteborg, Sweden, Report 1999-12-30.

8. DAVIDSSON, I:DEUTSCHER, HELL, W: LINDER, A ; LöVSUND, P.; SVENSSON, M.Y. (1998) H uman Volunteer Kinematics in Rear-end Sled Collisions. SA E paper no. 1998-13-0020, Proc. Int. IRCOBI Conf., pp. 289-302.

9. DAVIDSSON, J.: LÖVSUND, P.; ONO, K.: SVENSSON, M.Y.: INAMI, S (1999): A comparison between volunteer, BioRID P3 and $\mathrm{H}$ ybrid III performance in rear impacts. 1999 International IR C O BI C onference on the Biomechanics of Impact, Barcelona, Spain, SA E paper no. 1999-13-0011 (C rash Prevention and Injury Control, accepted)

10. DAVIDSSON, J. (2000): Development of a M echanical M odel for Rear Impacts: Evaluation of Volunteer Responses and Validation of the M odel. Dissertation, C rash Safety Division, Chalmers U niversity of Technology, Göteborg, Sweden, ISBN 91-7197-924-7.

11. Deng, B.: Begeman, P.C.: YANG, K.H.: TASHMAN, S.; KING A.I (2000): Kinematics of H uman Cadaver Cervical Spine During Low Speed Rear-End Impacts. STA PP C ar C rash Journal, Vol. 44, pp. 171-188.

12. JAKOBSSON, L. (2000): A IS 1 neck injuries in rear-end car impacts Biomechanical guidelines and evaluation criteria based on accident data and parameter studies. Licentiate Thesis, C rash Safety Division Chalmers U niversity of Technology, Sweden, www.chalm-ers.se.

13. JAKOBSSON L: LUNDELL B: NORIN H: ISAKSSON-HELLMAN I. (2000a): W HIPS - Volvo's whiplash protection study. A ccident A nalysis and Prevention, Vol. 32, pp. 307-319.

14. JAKOBSSON, L.; NORIN, H .; ISAKSSON-HELLMAN, I. (2000b) Parameters Influencing the Risk of A ISI N eck Injuries in Frontal and Side Impacts. Proc. IRC OBI C onf. M ontpellier, France, September 20-22, pp. 235-247.

15. Johansen, M.K.; G raven-N Ielsen, T.; O lesen, A .; A rendt-N Ielsen, L. (1999): G eneralised muscular hyperalgesia in chronic whiplash syndrome. Pain 83 (1999) 229-234.

16. Karlsson, E-L.; Falkheden-Henning, L.; OLsSOn, I.; Bunketorp, 0 (2000): C linical findings at a primary examination by physiotherapist and the outcome one year after neck sprain in traffic accidents. J Traffic M edicine (2000) Vol. 28, No 2S, p. 47.

17. Kleinberger, M.; Sun, E.; Eppinger, R.; KuPPA, S.; SAUl, R. (1998): Development of Improved Injury $C$ riteria for the A ssessment of A dvanced A utomotive Restraint Systems, N H T SA Docket 98-4405-9, US Dept. of Transportation, W ashington DC

18. KRAFFT M. (2000): Influence of velocity change and car acceleration on short- and long-term disability risk in rear impact. In: Eds. YOGANANDAN, N; PINTAR, F.A .: Frontiers in W hiplash Trauma. IOS Press, The N etherlands, ISBN 158603012 4, pp. 99-117.

19. van den Kroonenberg, A.; Philippens, M.; CAPpon, H; W Ismans, J HELL, W.; LA N GWIEDER, K. (1998): H uman head-neck response during low-speed rear end impacts. SA E paper no. 983158, 42nd
A nnual Stapp Car C rash C onference, Tempe, A rizona, U SA.

20. Kullgren, A: Maria Krafft M: N Ygren, A : TINgVAlL, C (2000): $\mathrm{N}$ eck injuries in frontal impacts: influence of crash pulse characteristics on injury risk. A ccident A nalysis and Prevention 32 (2000) 197-205.

21. Lövsund, P.; N ygren, Å.; Salen, B.; Tingvall, C. (1988): N eck Injuries in Rear End Collisions among Front and Rear Seat $\mathrm{O}$ ccupants. Proc. Int. IR C OBI C onference Biomech. of Impacts, Bergisch-G ladbach, F.R.G., pp. 319-325.

22. Minton, R.; Murray, P.; Stephenson, W.; Gala sko C.S.B. (2000) W hiplash injury - are current head restraints doing their job? A ccident A nalysis and Prevention 32 (2000) 177-185.

23. M U SER, M.; WA LZ, F.; Zellmer, H . (2000): Biomechanical significance of the rebound phase in low speed rear end impacts. 2000 International IR C OBI C onference on the Biomechanics of Impact, M ontpellier, France, pp. 393-410

24. ONO, K.; KANEOKA, K.; W ITTEK, A .; KA JZER, J. (1997): Cervical injury mechanism based on the analysis of human cervical vertebra motion and head-neck-torso kinematics during low-speed rear impacts. 41st A nnual Stapp C ar C rash Conference, Florida, U SA, SAE paper no. 973340

25. ONO, K.; KA NEOKA, K., InAmI, S. (2000): A nalysis of Seat Properties on $\mathrm{H}$ uman Cervical Vertebral M otion in Low-Speed Rear-End Impacts. In: Eds. YOGANANDAN, N : PINTAR, F. A .: Frontiers in W hiplash Trauma. IOS Press, The N etherlands, ISBN 1586030124

26. PANJABI, M.M.; WANG, J.L.; DeLSON, N. (1999): N eck injury criterion based on intervertebral motions and its evaluation using an instrumented neck dummy. 1999 International IRC O BI Conference on the Biomechanics of Impact, Barcelona, Spain, SA E paper no: 1999-13-0043.

27. RyAn GA, TAYlor GW, MoOre VM, Dolinis J. (1994): N eck strain in car occupants: injury status after 6 months and crash-related factors. Injury 1994, 25(8):533-7.

28. Sheather-Reid, R.B.; COHEN, M.L. (1998): Psychophysical evidence for a neuropathic component of chronic neck pain. Pain 75(1998) 341-347.

29. Siegmund, G.P.; BRAuLt, J.R. (2000): Role of Cervical M uscles During W hiplash. In: Eds. YoganANDAN, N ; PINTAR, F.A.: Frontiers in W hiplash Trauma. IOS Press, The N etherlands, ISBN 158603 0124.

30. Spitzer, W.O.; Skovron, M.L.; SA Lmi, L.R. et A L. (1995): Scientific M onograph of the Q uebec Task Force on W hiplash-A ssociated Disorders: Redefining "W hiplash" and Its M anagement. Spine, Supplement 2.

31. Sturzenegger, M.; Radanov, P.B.; Di Stefano, G. (1995): The effect of accident mechanisms and initial findings on the long term course of whiplash. J. N eurol (1995) 242:443-449.

32. SVENSSON, M.Y.; BOSTRÖM, O.; DAVIDSSON, J.; HANSSON, H .-A.; HÅLAND, Y.; LÖVSUND, P.; SUNESON, A .; SÄ LJÖ, A . (2000): N eck Injuries in $\mathrm{C}$ ar $\mathrm{C}$ ollisions - A Review Covering a possible Injury $\mathrm{M}$ echanism and The Development of a N ew R ear-Impact Dummy. A ccident A nalysis and Prevention, 32 (2000) 167-175.

33. TAYLOR, J.R.: TWOMEY, L.T.: KAKULAS, B.A. (1998): Dorsal root ganglion injuries in 109 blunt trauma fatalities. Injury, vol. 29, N o. 5 pp. 335-339.

34. TEMmING, J.; Zobel, R. (1998) Frequency and Risk of Cervical Spine Distortion Injuries in Passenger C ar A ccidents: Significance of H uman Factors Data. Int. IRC O BI C onf., pp. 219-234.

35. W In Kelstein, B.A.; N IGHTINGALE, R.W.; RiChARDSON, W.J.; M YeRS, B.S (1999): Cervical facet joint mechanics: Its application to whiplash injury. 43rd Stapp Car C rash Conference, California, USA, SA E Paper no. 99SC 15

36. YOGANANDAN, N; PINTAR, F.A. (2000a): Frontiers in Whiplash Trauma. IOS Press, The N etherlands, ISBN 158603012

37. YoganANDAN, N; PINTAR, F.A. (2000b): M echanics of Head A che and $N$ eck Pain in W hiplash. In: Eds. Yoganandan, N; Pintar, F.A. Frontiers in W hiplash Trauma. IOS Press, The N etherlands, ISBN 1 586030124 , pp. 173-185

38. YoganANDAN, N; PINTAR, F.A.; StemPer, B.D.; SCHLICK, M.B.; PhILIPPEN S,M .; W ISMANS, J. (2000): Biomechanics of H uman $\mathrm{O}$ ccupants in Simulated Rear Crashes: Documentation of $\mathrm{N}$ eck injuries and $\mathrm{C}$ omparison of Injury C riteria. STA PP C ar C rash Journal, Vol. 44, pp. 189-204.

This material was presented at the International Congress on W hiplash A ssociated Disorders, Berne, Switzerland, M arch 8 to 10, 2001. The paper appeared originally in the book "W hiplash A ssociated D isorders" - medical, biomechanical and legal aspects, published by Staempfli Publishers Ltd, Berne 2002. The paper is published in N orth A merica in Pain Research \& M anagement with the permission of Staempfli Publishers Ltd. 


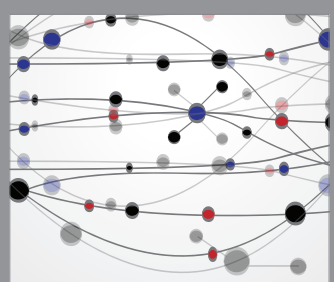

The Scientific World Journal
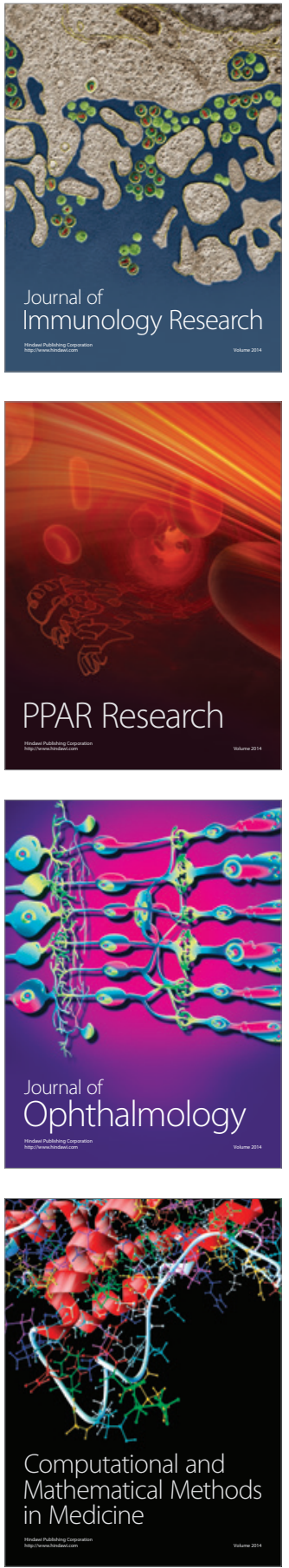

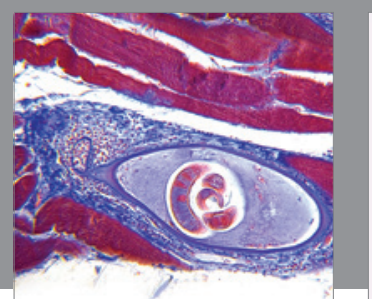

Gastroenterology Research and Practice

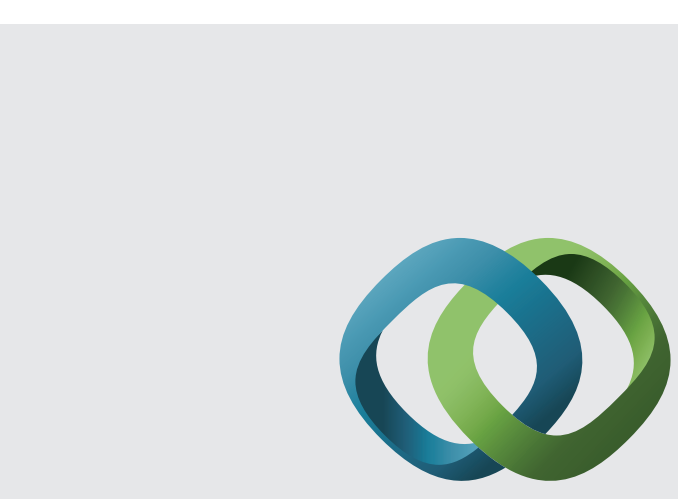

\section{Hindawi}

Submit your manuscripts at

http://www.hindawi.com
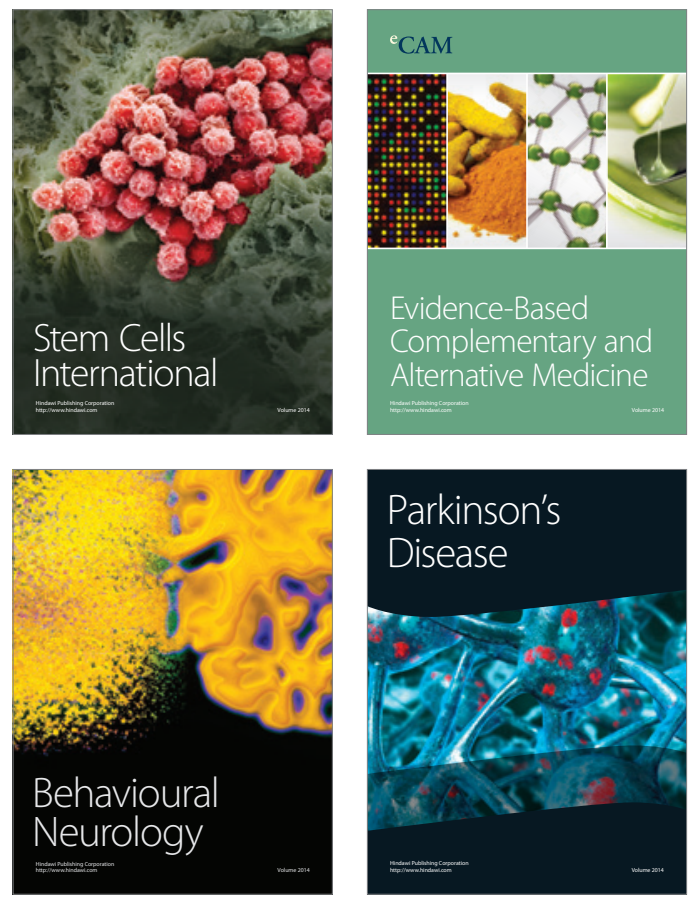
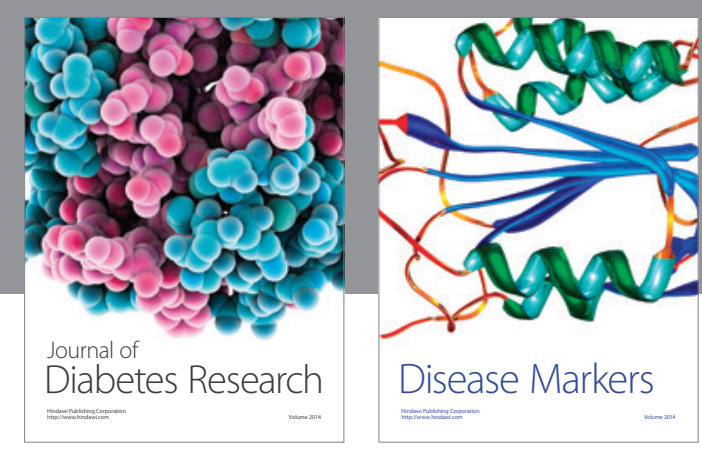

Disease Markers
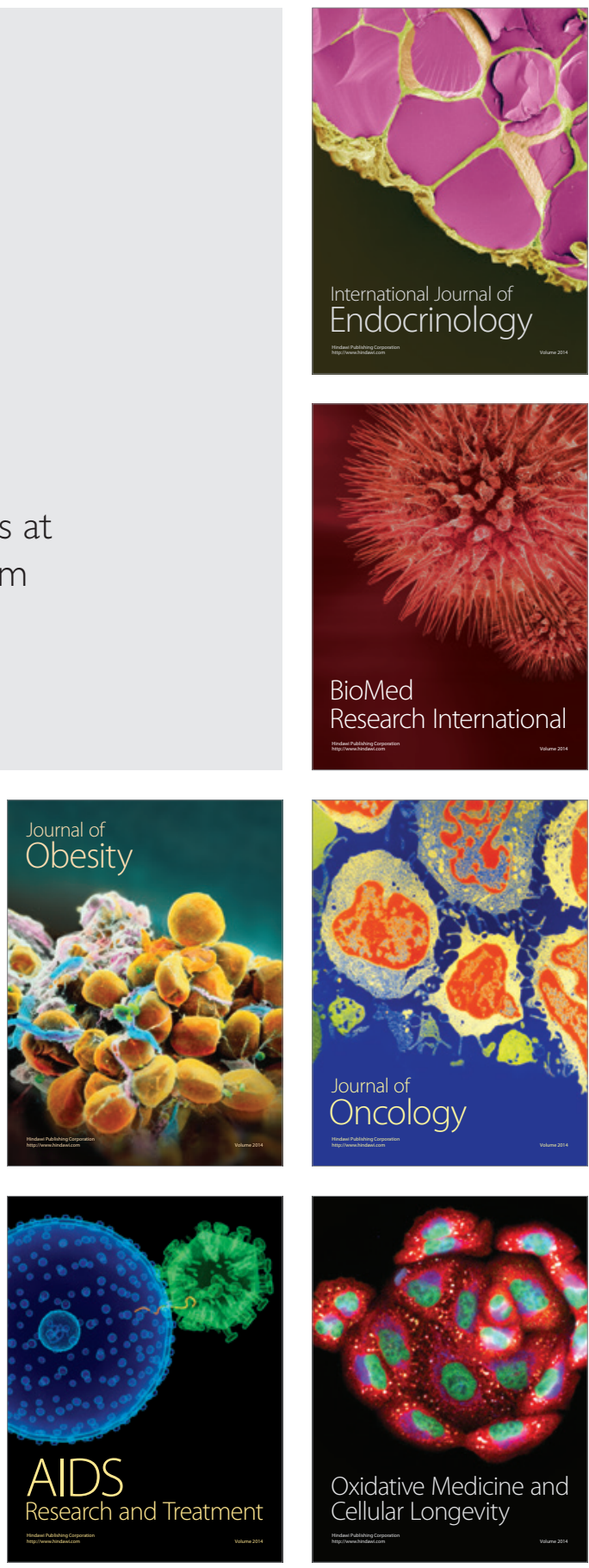